\title{
NUTRIENT ALLOCATION STRATEGIES TO EGGS BY LESSER SNOW GEESE (CHEN CAERULESCENS) AT A SUB-ARCTIC COLONY
}

\author{
Keith A. Hobson, ${ }^{1,6}$ Christopher M. Sharp, ${ }^{2}$ Robert L. Jefferies, ${ }^{3}$ \\ ROBERT F. ROCKWELL, ${ }^{4}$ AND KenNeTH F. ABRAHAM ${ }^{5}$ \\ ${ }^{1}$ Environment Canada, 11 Innovation Boulevard, Saskatoon, Saskatchewan S7N 3H5, Canada; \\ ${ }^{2}$ Environmental Life Sciences Graduate Program, 1600 West Bank Drive, Peterborough, Ontario K9J 7B8, Canada; \\ ${ }^{3}$ Department of Ecology and Evolutionary Biology, University of Toronto, 25 Willcocks Street, Toronto, Ontario M5S 3B2, Canada; \\ ${ }^{4}$ Department of Vertebrate Zoology, American Museum of Natural History, Central Park West at 79th Street, \\ New York, New York 10024, USA; and \\ ${ }^{5}$ Ontario Ministry of Natural Resources, 2140 East Bank Drive, DNA building, Peterborough, Ontario K9J 7B8, Canada
}

\begin{abstract}
The relative allocation of endogenous- and exogenous-derived nutrients to reproductive investment in Arctic-nesting geese is affected by body size, migration distance, and proximate conditions on the wintering, staging, and breeding grounds prior to clutch initiation. We used $\delta^{13} \mathrm{C}$ and $\delta^{15} \mathrm{~N}$ measurements of muscle tissue and egg lipid-free yolk and albumen and $\delta^{13} \mathrm{C}$ analysis of abdominal fat and egg yolk lipids, together with isotopic analyses of foraging plants, to quantify the relative use of endogenous and exogenous reserves in egg production in a breeding population of sub-Arctic Lesser Snow Geese (Chen caerulescens caerulescens) on the Cape Churchill Peninsula, Manitoba, from 2005 to 2008. We used a concentration-dependent, two-isotope, three-source Bayesian (SIAR) mixing model to derive estimates of endogenous reserves to egg macronutrients and a single-isotope $\left(\delta^{13} \mathrm{C}\right)$, two-source (exogenous vs. endogenous) Bayesian model to estimate the source of lipids to eggs. Endogenous protein contributions to eggs were similar to those found using identical Bayesian analytical methods for the larger-bodied Greater Snow Goose (Chen caerulescens atlantica) breeding in the Canadian High Arctic and were on the order of 30\%. However, endogenous lipid contributions were considerably greater for the population of Lesser Snow Geese (mean annual contribution of $55.5 \%$ vs. $22.3 \%$ ). This suggests that advantages of larger body size for transport of body lipid reserves for long distances may be countered by the need to use lipids to fuel migration over greater distances. In addition, feeding opportunities of Greater Snow Geese upon arrival at their more distant breeding sites were likely adequate to offset a shorter breeding season and longer development times for offspring than at lower-latitude sites. Received 6 April 2010, accepted 25 September 2010.
\end{abstract}

Key words: ${ }^{13} \mathrm{C}$, Cape Churchill, eggs, endogenous- and exogenous-derived nutrients, Hudson Bay Lowlands, migration, ${ }^{15} \mathrm{~N}$, reproductive strategy.

\section{Estrategias de Asignación de Nutrientes a los Huevos por parte de Chen caerulescens en una Colonia Subártica}

RESUMEN.-La asignación relativa de nutrientes derivados endógena y exógenamente a la inversión parental en los gansos que crían en el Ártico es afectada por el tamaño corporal, la distancia de migración y condiciones próximas en las áreas de invernada, parada y reproducción antes de la iniciación de las posturas. Para cuantificar el uso relativo de reservas endógenas y exógenas en la producción de huevos en una población subártica de Chen caerulescens caerulescens en la península de Cape Churchill (Manitoba), entre 2005 y 2008 usamos medidas de $\delta^{13} \mathrm{C}$ y $\delta^{15} \mathrm{~N}$ tomadas en tejido de músculo y de muestras libres de lípidos de vitelo y albumen de los huevos, así como análisis de $\delta^{13} \mathrm{C}$ de la grasa abdominal y de los lípidos del vitelo en conjunto con análisis isotópicos de las plantas de forrajeo. Utilizamos un modelo bayesiano mixto dependiente de la concentración, con dos isótopos y tres fuentes, para derivar estimados de las reservas endógenas invertidas en macronutrientes de los huevos. Además, empleamos un modelo bayesiano basado en un isótopo $\left(\delta^{13} \mathrm{C}\right)$ y dos fuentes (exógenas vs. endógenas) para estimar la fuente de los lípidos presentes en los huevos. Las contribuciones endógenas de proteína a los huevos, del orden del $30 \%$, fueron similares a las encontradas mediante análisis bayesianos idénticos para la forma de mayor tamaño Chen caerulescens atlantica que cría en el Ártico alto canadiense. Sin embargo, las contribuciones endógenas de lípidos fueron considerablemente mayores en la población de C. c. caerulescens (contribución media anual de 55.5\% vs. 22.3\%). Esto sugiere que las ventajas del tamaño corporal mayor para el transporte de reservas lipídicas corporales a lo largo de distancias grandes pueden ser contrarrestadas por la necesidad de utilizar los lípidos como combustible de la migración a mayores distancias. Además, las oportunidades de alimentación para C. c. atlantica tras arribar a sus sitios de cría más distantes probablemente fueron adecuadas para ajustar una temporada de cría más corta y tiempos de desarrollo de las crías más largos en comparación con sitios ubicados a menor latitud.

${ }^{6}$ E-mail: keith.hobson@ec.gc.ca

The Auk, Vol. 128, Number 1, pages 156-165. ISSN 0004-8038, electronic ISSN 1938-4254. @ 2011 by The American Ornithologists' Union. All rights reserved. Please direct all requests for permission to photocopy or reproduce article content through the University of California Press's Rights and Permissions website, http://www.ucpressjournals. com/reprintInfo.asp. DOI: 10.1525/auk.2010.10086 
IN MIGRATORY BIRDS, the allocation of nutrients to reproduction versus migration represents a fundamental life-history tradeoff. The energetic demands of long-distance migration constrain the amount of nutrients that birds can bring with them to the breeding grounds for early-season maintenance, egg formation, and incubation. This tradeoff is especially important in the case of migrants that arrive at high-latitude breeding grounds, where they may need to fast while they wait for local foods to become available. Here, the relative demands of nutrient allocation for egg formation and maintenance before and after egg laying are especially crucial in determining reproductive success Geese breeding at high latitudes have classically been considered "capital" breeders, whereby a substantial amount of stored endogenous nutrients are used by females to form eggs (Ryder 1970, Ankney and MacInnes 1978, Raveling 1978, Drent and Daan 1980, Ebbinge et al. 1982, Meijer and Drent 1999). This strategy is particularly viable for large-bodied geese that can carry nutrient stores acquired at the wintering and staging grounds without incurring high costs of transporting this extra mass (Klaassen 2003). The alternative, "income" strategy is when animals use external resources (exogenous reserves) for reproduction that are available at the time of breeding (Drent and Daan 1980, Meijer and Drent 1999). Originally, the distinction between these two breeding strategies was based solely on the deposition of protein and energy in eggs (Drent and Daan 1980), but more recently all reproductive investment (e.g., energy used for incubation) up to the time of hatch has been included in the assessment. As Owen and Reinecke (1979) and Thomas (1988) pointed out, this dichotomy represents two ends of a continuum, and resource acquisition falls in-between in most species.

Recently, Klaassen et al. (2006) reviewed the pertinent hypotheses concerning the prevalence of capital versus income breeding in birds that travel to breed. The "body-size hypothesis" postulates that larger-bodied migratory birds breeding at high latitudes invest more endogenous reserves into reproduction because they need to breed early, owing to longer incubation and chick-rearing periods, and they may be constrained by low food availability on arrival, as conditions are often marginal for plant growth. The extent to which birds are able to forage on their breeding grounds in the days immediately ahead of laying is likely to vary from season to season, independent of body size per se. Because of the allometric relationship that links flight costs to fuel load, a complicating factor is the distance over which a bird must travel with endogenous stores. An example is the Greater Snow Goose (Chen caerulescens atlantica), which breeds on Bylot Island in the High Arctic. Despite the large body mass of females prior to egg laying and incubation ( $3.1 \mathrm{~kg}$; Choinière and Gauthier 1995) and, therefore, the potential for high levels of endogenous reserves to be used for reproduction, females forage extensively in most years for fat and protein before egg laying, following a journey of 3,000 km from their main staging area in southern Quebec (Choinière and Gauthier 1995, Gauthier et al. 2003; Fig. 1). As long as follicle development has not occurred, geese that are in the vicinity of the breeding ground are likely to allocate local exogenous nutrients to eggs during the period of rapid follicle development and albumen synthesis, provided that nutrients are available. In the Arctic, day length increases with latitude in summer; however, the overall season length decreases with latitude. In general, we expect highlatitude breeders within a species to be more time-constrained than low-latitude breeders, and so expect the probability for capital breeding to increase with latitude. However, comparative data on nutrient allocations to reproduction across latitudes are sparse.

Recent developments in the use of stable isotopes as natural tracers of endogenous and exogenous nutrients in eggs have begun to provide a more quantitative approach to the evaluation of the degree of capital versus income reproductive strategies (Hobson et al. 2000, 2004, 2005; Gauthier et al. 2003; Morrison and Hobson 2004; Hobson 2006; Bond et al. 2007). The method is appropriate when birds move between two isotopic landscapes or isoscapes to commence breeding (e.g., Yerkes et al. 2008). Provided that eggs produced from local foods differ isotopically from those that would be produced from endogenous protein and lipid reserves, the isotope approach can provide an estimate of the relative contributions from each source via simple isotopic mixing models. Gauthier et al. (2003) provided the first use of this technique for high-latitude breeders in their study of Greater Snow Geese breeding on Bylot Island, Nunavut. Over a 3-year period, they determined that geese followed a mixed capital-income strategy of allocating nutrients to eggs and estimated that endogenous protein reserves contributed only about $27 \%$ of albumen and $33 \%$ of yolk and that stored lipids contributed about $20 \%$ of yolk lipid. This work countered previous assumptions of much greater roles of endogenous reserves for

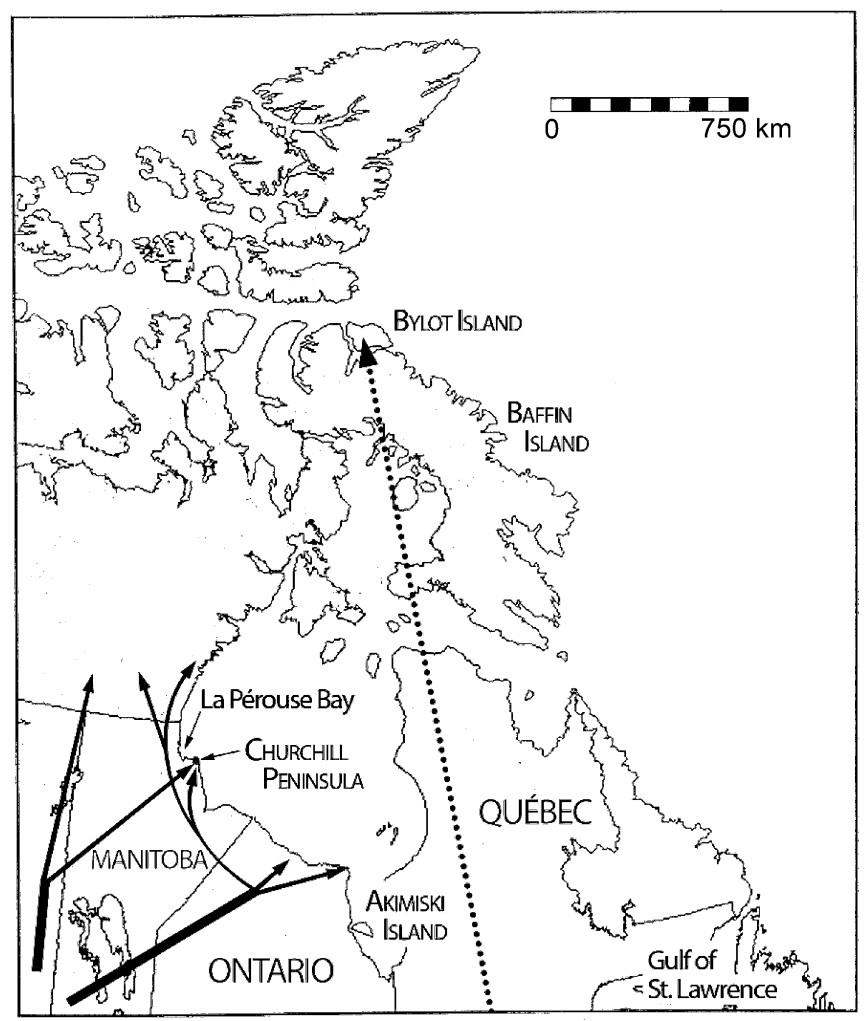

FIG. 1. Map of the spring migration routes of Lesser Snow Geese (solid lines) and Greater Snow Geese (dotted line) to nesting grounds in the Hudson Bay region and on Bylot Island, respectively. The routes are only approximate, based on observations of local residents and band (ring) returns. The Hudson Bay Lowlands extends from James Bay, in which Akimiski Island is located, across northern Ontario, northeastern Manitoba, and northward into the southern coastal portion of Nunavut bordering the Hudson Bay. 
reproduction in high-latitude geese and contributed to a paradigm shift in the way we consider nutrient allocation strategies in these birds. As mentioned above, the birds feed extensively on arrival at Bylot before they initiate egg laying.

More recently, Schmutz et al. (2006) used the isotope approach to determine the endogenous contributions to eggs in Brant (Branta bernicla) and Emperor Geese (Chen canagica) in the Yukon-Kuskokwim Delta, Alaska. Approximately $41 \%$ and 55\%, respectively, of the protein in egg yolks was derived from endogenous sources. There was high variability in the percentage contribution of endogenous and exogenous stores to eggs between individuals, which implied that foraging patterns along the migration route and on the breeding grounds were dissimilar among individuals. Spring staging habitats were particularly important as a source of food for Emperor Geese, but the data indicated that not all individuals foraged in these habitats to the same degree.

We used the isotope approach to trace the contributions of endogenous and exogenous nutrients to egg formation in Lesser Snow Geese (Chen caerulescens caerulescens) at a sub-Arctic breeding colony on the Cape Churchill Peninsula in the vicinity of La Pérouse Bay, Manitoba, from 2005 to 2008. This subspecies is smaller than the Greater Snow Goose (mean female mass prior to egg laying: $2.5 \mathrm{~kg}$; Ankney and MacInnes 1978). The midcontinent population, to which this local population belongs, stages in inland agricultural areas of the United States and southern Canada, feeding on corn (Zea mays). The final stages of the traditional migration route are thought to be from agricultural fields in southern Manitoba to the coastal wetlands of northern Ontario, followed by a northwesterly, stepping-stone migration within the Hudson Bay Lowlands to the Churchill region and beyond, as permitted by the retreating snowline (Fig. 1).

Local populations of Lesser Snow Geese whose breeding grounds are located in the Hudson Bay's coastal lowlands have to travel a much shorter migration distance than Greater Snow Geese. Smaller body size was expected to act as a factor reducing the degree to which these birds were capital breeders. In addition, the shorter migration distance lessens not only the costs of transporting endogenous reserves but also the need for these reserves because of the potentially longer snow-free season in the sub-Arctic. A further consideration is that the proximity of the immediate coastal areas in Ontario and Manitoba to the frozen Hudson Bay in early spring results in an extended season of snow and ice cover, producing physical conditions characteristic of sites farther north at the same time of year that potentially delay the growth of forage plants and access to breeding sites. The effect is particularly noticeable between the frozen seashore and the first $3 \mathrm{~km}$ inland and has been called the "winterization of summer" (Rouse 1991). As a result, geese often feed extensively in wet sedge meadows in the Hudson Bay Lowlands beyond this zone as they wait for the coastal lands to thaw (Abraham and Jefferies 2010). Hence, we postulated that the extent to which the geese on the Cape Churchill Peninsula used a capital breeding strategy was likely to vary annually depending on local weather and growing conditions during the final stages of migration and on the breeding grounds. We sought to compare nutrient allocation strategies in Lesser Snow Geese at this sub-Arctic colony and at the lower-latitude colony on Akimiski Island in southern Hudson Bay, Nunavut (Sharp 2010), with the findings of Gauthier et al. (2003) for a larger-bodied subspecies in the High Arctic. Our analysis was conducted over four successive breeding seasons in order to embrace interyear variation in weather conditions on the Cape Churchill Peninsula.

\section{Methods}

Cape Churchill Peninsula colony.-Lesser Snow Geese began nesting in the vicinity of La Pérouse Bay on the Cape Churchill Peninsula, Manitoba, in the 1950s (Cooke et al. 1995). Since that time, the local population has increased to 44,500 pairs, based on the aerial surveys in 1997 and 2006 (Ross et al. 2004, R. F. Rockwell et al. unpubl. data), and they nest over a much wider geographic area on the Cape Churchill Peninsula, from low-lying coastal wetlands $20 \mathrm{~km}$ east of Churchill to south of the Broad River on the east coast of the peninsula (Rockwell and Gormezano 2009).

Field collections.-Samples of breast muscle representing the body protein pool and abdominal fat (but excluding mesenteric fat attached to the intestine loops) representing stored lipids were taken annually from 6 to 8 recently arrived birds that were shot by local residents of Churchill. The birds appeared to be local breeders and not staging birds and were collected within 3 to 4 days of egg collections and in the vicinity of the colony. Sex and reproductive condition were not established for collected birds. In recent years, the majority of geese that nested farther north have flown high and fast over the Cape Churchill Peninsula without staging, and no staging birds were reported north of Churchill at the time of collections (R. L. Jefferies and R. F. Rockwell unpubl. field notes). The tissues were kept frozen in plastic bags until they were shipped to the Environment Canada laboratory of K.A.H. in Saskatoon by air in an ice cooler. Lesser Snow Goose eggs were collected at, or close to, clutch completion in late May or early June from 2005 to 2008. The most discolored egg was collected from each nest and was assumed to be the first-laid egg. Each year, between 21 and 31 eggs were taken from nests located in a wetland on the north coast of the Cape Churchill Peninsula between Knight's Hill and Christmas Lake $\left(58^{\circ} 43^{\prime} \mathrm{N}, 93^{\circ} 38^{\prime} \mathrm{W}\right)$. Peak initiation and peak hatch were, respectively, 29 May and 22 June (2005), 19 May and 12 June (2006), 17 May and 13 June (2007), and 1 June and 24 June (2008). Eggs were heated in water at $85^{\circ} \mathrm{C}$ for $90 \mathrm{~min}$ and were stored frozen for shipment to Saskatoon, where both tissues and eggs were frozen prior to the stable-isotope analysis. We also collected plant material on which the geese foraged during the preegg laying, laying, and incubation stages. The material included the swollen leaf bases of Marsh Fleabane (Senecio congestus), the swollen base of shoots of Water Sedge (Carex aquatilis), roots and rhizomes of Creeping Alkaligrass (Puccinellia phryganodes), and shoots of Hoppner's Sedge (C. subspathacea) (nomenclature follows Porsild and Cody 1980). The last two are the dominant species in the intertidal salt marsh and are the preferred forage during the posthatch period, though roots and rhizomes of $P$. phryganodes are grubbed at melt before aboveground growth commences. In the early season, once the ground has thawed, the bases of the leaves of the basal rosettes of $S$. congestus are commonly eaten and there is extensive shoot-pulling of C. aquatilis shoots. The sedge is common in freshwater mineral-rich mires and the S. congestus occurs in disturbed brackish habitats (Jefferies et al. 2003). All plant material was washed in deionized water to remove soil particles, dried in an oven for 1 week at $50^{\circ} \mathrm{C}$, and bagged in envelopes.

Stable-isotope analyses.-Eggs were cut in half while partially frozen. From one half, egg yolk was excavated from the center of 
the egg and albumen taken randomly from the outer layer. These materials were freeze-dried. Lipids were extracted from the freezedried yolk using a 2:1 chloroform: methanol solution. Lipids were retrieved from the solvent by evaporation under a fume hood and then frozen prior to isotopic analysis. Lipid-free yolk and albumen were similarly dried and stored frozen prior to analysis. Plant material was further cleaned with distilled water, freeze dried, and powdered. Tissue subsamples were powdered and then weighed in tin cups for stable-isotope analysis. In 2005, we selected a random set of seven eggs to compare isotope measurements for lipid-free yolk and yolk lipid excavated from the center, middle, and outer portions of the cross-sectioned yolk.

Samples were analyzed for $\delta^{13} \mathrm{C}$ and $\delta^{15} \mathrm{~N}$ using continuousflow isotope mass spectrometry (CFIRMS) at the Department of Soil Science, University of Saskatchewan. Samples were combusted in a Robo-Prep elemental analyzer $\left(1,250^{\circ} \mathrm{C}\right)$ and combustion gases analyzed in an interfaced Europa 20:20 mass spectrometer (Europa Scientific, Northwich, United Kingdom). Two working standards (egg albumen and whale baleen) were analyzed for every five unknowns of egg tissues. For plant material, a pea grain standard was used. Stable-isotope ratios were calibrated to the international standards (Vienna Pee Dee Belemnite and AIR for carbon and nitrogen, respectively; see Hobson 1995). Based on within-run replicate analyses, measurement precision for $\delta^{13} \mathrm{C}$ and $\delta^{15} \mathrm{~N}$ values were estimated to be $\pm 0.1 \%$ and $\pm 0.3 \%$, respectively.

Mixing models.-The percent contribution of endogenous and exogenous nutrients to eggs can be estimated using isotopic mixing models. We investigated the use of a recently developed Bayesian mixing-model approach. Bayesian mixing models have the advantage of being able to readily propagate error in several parameters used in models and to apply any prior probabilities associated with knowledge of species' ecology. Several models are currently available to practitioners, but only SIAR (Parnell et al. 2010) incorporates a concentration-dependent component similar to the non-Bayesian IsoConc mixing model of Phillips and Koch (2002). The incorporation of tools to account for differences in elemental (i.e., $[\mathrm{C}]$ and $[\mathrm{N}]$ ) concentrations among sources of nutrients available to birds is crucial for investigations of herbivores because their (endogenous) body protein reserves differ substantially in these concentrations compared to (exogenous) plants. In addition, models must also consider differences in assimilation of $\mathrm{N}$ and $\mathrm{C}$ from plant material (Gauthier et al. 2003). The stableisotope approach, improved greatly by the use of Bayesian models, is still heavily dependent on the assumption that the tissue-egg isotopic discrimination factors corresponding to the mobilization of endogenous tissues to eggs follow those derived experimentally by Hobson (1995) for carnivorous birds (falcons) following an income breeding strategy. This approach worked well for the investigation of Gauthier et al. (2003) for snow geese breeding at the High Arctic colony on Bylot Island. However, it is unclear to date just how valid this approach is for the mobilization of endogenous reserves to eggs and how sensitive the approach is to variance in discrimination values. For these reasons, we compared our results to those of Gauthier et al. (2003) and Sharp (2010) only after we reanalyzed their data for Greater and Lesser snow geese, respectively, using identical (Bayesian) methods described here for our sample of Lesser Snow Geese. In addition, we examined the effect of varying assumed isotopic discrimination factors between eggs and endogenous reserves, because these values have not been measured experimentally.

Following the approach of Gauthier et al. (2003), based in turn on the captive work of Hobson (1995), we assumed a $\delta^{15} \mathrm{~N}$ discrimination factor of $+3.4 \%$ between plant diet and egg albumen and lipid-free yolk and the same factor for discrimination between breast muscle to these egg components. A plant diettissue $\delta^{13} \mathrm{C}$ discrimination value of $+1.5 \%$ was used for egg albumen and $0.0 \%$ for lipid-free yolk. For the mobilization of carbon from breast muscle to egg albumen and lipid-free yolk, we used discrimination factors of $+0.9 \%$ and $0.0 \%$, respectively. For the single isotope $\left(\delta^{13} \mathrm{C}\right)$ model involving contributions of lipids, we assumed a food-to-yolk lipid discrimination of $-2.6 \%$ and an abdominal fatto-yolk lipid discrimination of $0.0 \%$. We arbitrarily applied an error (SD) of $1.0 \%$ for all discrimination factors in the SIAR model. While SIAR allowed us to incorporate different $[\mathrm{C}]$ and $[\mathrm{N}]$ values corresponding to plant and endogenous sources of nutrients, we adjusted these values to also accommodate differential assimilation efficiencies for geese following the approach of Gauthier et al. (2003). This involved the use of directly measured elemental concentration values of plants and goose muscle and then modifying these in SIAR to account for an $80 \%$ assimilation efficiency of N compared with a $35 \%$ efficiency for C. Errors associated with these modified concentration values were derived from our data (i.e., \pm SD). We similarly incorporated error associated with concentration of $\mathrm{C}$ and $\mathrm{N}$ in muscle tissue for the endogenous endpoint but here assumed $100 \%$ assimilation efficiency for both elements. We conducted mixing-model analyses using SIAR with noninformative priors. SIAR reports mean and median contributions of endpoints to the mix together with the $95 \%$ confidence interval.

\section{Results}

Mixing model.-Plants eaten by Lesser Snow Geese during egg formation at La Pérouse Bay did not differ in their $\delta^{13} \mathrm{C}$ values $(F=1.8, \mathrm{df}=3$ and $23, P=0.178)$ but differed in their $\delta^{15} \mathrm{~N}$ values $(F=19.7, \mathrm{df}=3$ and 23, $P<0.001$; Table 1$)$. A Tukey post hoc examination showed that $S$. congestus was more enriched in ${ }^{15} \mathrm{~N}$

TABLE 1. Stable-isotope values (means \pm SE; $n$ shown in parentheses) and percent carbon and nitrogen content of plants eaten by Lesser Snow Geese at Cape Churchill Peninsula, Manitoba, during the pre-initiation, initiation, and incubation of clutches.

\begin{tabular}{llllr}
\hline Sample & Type & $\delta^{13} \mathrm{C}(\%)$ & $\% \mathrm{C}$ & $\delta^{15} \mathrm{~N}(\%)$ \\
\hline Puccinellia phryganodes (7) & Rhizomes & $-28.0 \pm 0.8$ & $46.2 \pm 1.2$ & $1.7 \pm 0.7$ \\
Carex aquatilis (4) & Shoots & $-28.2 \pm 0.3$ & $45.8 \pm 0.3$ & $2.9 \pm 0.8$ \\
Senecio congestus (10) & Shoots & $-27.9 \pm 0.8$ & $43.0 \pm 1.1$ & $4.2 \pm 0.4$ \\
C. subspathacea (4) & Shoots & $-29.0 \pm 0.4$ & $46.8 \pm 0.5$ & $5.3 \pm 0.9$ \\
\hline
\end{tabular}


TABLE 2. Stable-isotope results for Lesser Snow Goose tissues taken at Cape Churchill Peninsula, Manitoba, from 2005 to 2008 (means \pm SE; $n$ shown in parentheses). Results of a one-way analysis of variance (ANOVA) describe interyear differences in mean tissue isotope values.

\begin{tabular}{|c|c|c|c|c|c|}
\hline \multirow[b]{2}{*}{ Sample } & \multicolumn{4}{|c|}{ Year } & \multirow[b]{2}{*}{ ANOVA } \\
\hline & 2005 & 2006 & 2007 & 2008 & \\
\hline \multicolumn{6}{|c|}{ Goose muscle } \\
\hline$\delta^{13} \mathrm{C}$ & $-22.0 \pm 0.6(7)$ & $-22.3 \pm 0.5(6)$ & $-21.9 \pm 0.6(7)$ & $-22.4 \pm 0.4(8)$ & $F=0.31, \mathrm{df}=3$ and $27, P=0.71$ \\
\hline$\delta^{15} \mathrm{~N}$ & $6.3 \pm 0.2(7)$ & $6.1 \pm 0.3(6)$ & $6.1 \pm 0.2(7)$ & $6.3 \pm 0.3(8)$ & $F=0.26, \mathrm{df}=3$ and $27, P=0.82$ \\
\hline \multicolumn{6}{|l|}{ Goose fat } \\
\hline$\delta^{13} \mathrm{C}$ & $-24.5 \pm 0.5(7)$ & $-24.2 \pm 0.4(6)$ & $-24.0 \pm 0.5(7)$ & $-24.6 \pm 0.3(8)$ & $F=0.81, \mathrm{df}=3$ and $27, P=0.33$ \\
\hline \multicolumn{6}{|l|}{ Egg lipid } \\
\hline$\delta^{13} \mathrm{C}$ & $-26.4 \pm 0.2(23)$ & $-27.9 \pm 0.3(21)$ & $-26.6 \pm 0.4(25)$ & $-28.1 \pm 0.2(31)$ & $F=10.74, \mathrm{df}=3$ and $99, P<0.0001$ \\
\hline \multicolumn{6}{|c|}{ Lipid-free yolk } \\
\hline$\delta^{13} \mathrm{C}$ & $-25.9 \pm 0.2(23)$ & $-25.9 \pm 0.2(21)$ & $-24.9 \pm 0.2(25)$ & $-25.7 \pm 0.2(31)$ & $F=4.90, \mathrm{df}=3$ and $99, P=0.003$ \\
\hline$\delta^{15} \mathrm{~N}$ & $6.7 \pm 0.1(23)$ & $6.5 \pm 0.2(21)$ & $6.6 \pm 0.1(25)$ & $6.6 \pm 0.1(31)$ & $F=0.23, \mathrm{df}=3$ and $99, P=0.88$ \\
\hline \multicolumn{6}{|l|}{ Albumen } \\
\hline$\delta^{13} \mathrm{C}$ & $-24.6 \pm 0.1(23)$ & $-24.1 \pm 0.1(21)$ & $-24.0 \pm 0.2(25)$ & $-24.5 \pm 0.1(31)$ & $F=4.47, \mathrm{df}=3$ and $99, P=0.005$ \\
\hline$\delta^{15} \mathrm{~N}$ & $6.4 \pm 0.1(23)$ & $6.8 \pm 0.2(21)$ & $6.9 \pm 0.1(25)$ & $6.6 \pm 0.1(31)$ & $F=3.52, \mathrm{df}=3$ and $99, P=0.018$ \\
\hline
\end{tabular}

than other plant sources. This result provided the possibility of analyzing our data using a three-source (endogenous, two exogenous) two-isotope $\left(\delta^{13} \mathrm{C}, \delta^{15} \mathrm{~N}\right)$ model. The Bayesian (SIAR) mixing model assumed two plant inputs, S. congestus $\left(\delta^{13} \mathrm{C}:-27.9 \pm\right.$ $0.8 \%$; $\delta^{15} \mathrm{~N}: 5.3 \pm 0.9 \%$ ) and "others" $\left(\delta^{13} \mathrm{C}:-28.4 \pm 0.5 \%\right.$; $\delta^{15} \mathrm{~N}: 2.5$ $\pm 0.7 \%$ ). Measured stable-isotope values for goose tissues across years are given in Table 2.

The endogenous contribution of nutrients to egg formation varied among years (albumen range: $27.2-38.4 \%$; yolk: $29.8-41.5 \%$, lipid: 44.2-70.6\%; Table 3). Among local plants, S. congestus was less important than all other plants combined, typically representing $<10 \%$ of the diet (Table 3 ). Other plants contributed about half the protein sources to eggs. We similarly derived estimates of the endogenous contribution of protein and lipids to eggs of Greater
Snow Geese by reexamining the data of Gauthier et al. (2003) using analytical procedures identical to those used here. The new analysis differed only slightly from the original linear mixing-model results based on Phillips and Koch (2002; Table 4). The endogenous contribution of proteins to egg albumen and lipid-free yolk in Lesser Snow Geese at Churchill were similar to that of Greater Snow Geese (mean annual contribution, respectively, of $32.3 \%$ vs. $34.5 \%$ for yolk and $33.0 \%$ vs. $29.7 \%$ for albumen; Table 4 ). However, we found a much greater contribution of endogenous lipids to egg lipids in Lesser Snow Geese at Cape Churchill Peninsula than that for Greater Snow Geese at Bylot Island (mean annual contribution of $55.5 \%$ vs. $22.3 \%$ ). Our reanalysis of first-egg data for the Akimiski Island colony of Lesser Snow Geese (Sharp 2010) showed low endogenous inputs of protein and lipids to first-laid eggs (Table 4)

TABLE 3. Estimates of mean exogenous (plants) and endogenous contributions of protein and lipid to egg formation in Lesser Snow Geese at Cape Churchill Peninsula, Manitoba, across years, using a three-endpoint (Senecio congestus, other plants, muscle), two-isotope $\left(\delta^{13} \mathrm{C}, \delta^{15} \mathrm{~N}\right)$ Bayesian mixing model (SIAR) for proteins and a two-endpoint (abdominal fat vs. all plants), single-isotope $\left(\delta^{13} \mathrm{C}\right)$ Bayesian (SIAR) mixing model for egg lipids, with $95 \%$ confidence intervals $(\mathrm{Cl})$.

\begin{tabular}{|c|c|c|c|c|c|c|c|c|}
\hline \multirow[b]{3}{*}{ Egg tissue } & \multicolumn{8}{|c|}{ Percent contribution } \\
\hline & \multicolumn{2}{|c|}{2005} & \multicolumn{2}{|c|}{2006} & \multicolumn{2}{|c|}{2007} & \multicolumn{2}{|c|}{2008} \\
\hline & Mean & $95 \% \mathrm{Cl}$ & Mean & $95 \% \mathrm{Cl}$ & Mean & $95 \% \mathrm{Cl}$ & Mean & $95 \% \mathrm{Cl}$ \\
\hline \multicolumn{9}{|l|}{ Yolk } \\
\hline Senecio & 9.9 & $0-22.6$ & 11.0 & $0-26.6$ & 6.8 & $0-20.1$ & 6.5 & $0-16.5$ \\
\hline Other plants & 61.8 & $50.1-72.9$ & 59.5 & $42.1-73.8$ & 51.8 & $32.8-69.6$ & 63.7 & $51.4-74.1$ \\
\hline Endogenous & 28.4 & $19.4-36.7$ & 29.5 & $2.3-38.7$ & 41.5 & $28.7-53.0$ & 29.8 & $21.5-38.2$ \\
\hline \multicolumn{9}{|l|}{ Albumen } \\
\hline Senecio & 13.5 & $0-30.6$ & 9.2 & $0-23.5$ & 8.1 & 0-19.8 & 9.8 & $0-23.0$ \\
\hline Other plants & 59.3 & $38.7-75.7$ & 52.5 & $33.8-67.3$ & 55.3 & $41.1-68.0$ & 60.6 & $44.2-73.7$ \\
\hline Endogenous & 27.2 & $17.3-37.7$ & 38.4 & $28.5-48.4$ & 36.6 & $27.1-45.7$ & 29.6 & $20.2-39.8$ \\
\hline \multicolumn{9}{|l|}{ Lipids } \\
\hline Exogenous & 29.4 & $18.6-38.8$ & 55.3 & $47.7-64$ & 37.6 & $28.2-46$ & 55.8 & $48.2-65$ \\
\hline Endogenous & 70.6 & $61.2-81.4$ & 44.7 & $36-52.3$ & 62.4 & $54-71.8$ & 44.2 & $35-51.8$ \\
\hline
\end{tabular}


TABLE 4. Comparison of estimated endogenous protein and lipid contributions to first-laid eggs of snow geese breeding in the Arctic across years (means \pm SE; ranges given in parentheses). To ensure comparability among studies, the same concentration-dependent Bayesian mixing-model approach (SIAR) was used for all data sets.

\begin{tabular}{|c|c|c|c|c|c|c|}
\hline \multirow[b]{2}{*}{ Species } & \multirow[b]{2}{*}{ Breeding grounds } & \multirow[b]{2}{*}{ Years } & \multicolumn{4}{|c|}{ Percentage of endogenous nutrients } \\
\hline & & & Yolk protein & Albumen & Yolk lipid & Study \\
\hline Lesser Snow Goose & $\begin{array}{c}\text { Cape Churchill, } \\
\text { Manitoba }\end{array}$ & $2005-2008$ & $\begin{array}{c}32.3 \pm 6.2 \\
(28.4-41.5)\end{array}$ & $\begin{array}{c}33.0 \pm 5.4 \\
(27.1-38.4)\end{array}$ & $\begin{array}{l}55.5 \pm 13.2 \\
(44.2-70.6)\end{array}$ & Present study \\
\hline Lesser Snow Goose & $\begin{array}{l}\text { Akimiski Island, } \\
\text { Nunavut }\end{array}$ & 2005-2008 & $\begin{array}{c}18.8 \pm 11.9 \\
(7.1-34.5)\end{array}$ & $\begin{array}{l}2.3 \pm 0.6 \\
(2.4-3.7)\end{array}$ & $\begin{array}{l}14.1 \pm 11.4 \\
(4.1-30.5)\end{array}$ & Sharp 2010 \\
\hline Greater Snow Goose & $\begin{array}{c}\text { Bylot Island, } \\
\text { Nunavut }\end{array}$ & 1999-2002 & $\begin{array}{l}33.5 \pm 1.3 \\
(32-34.6)\end{array}$ & $\begin{array}{c}29.7 \pm 0.5 \\
(29.3-30.3)\end{array}$ & $\begin{array}{c}22.3 \pm 2.0 \\
(20.7-24.5)\end{array}$ & Gauthier et al. 2003 \\
\hline
\end{tabular}

compared with the other two colonies. However, geese on Akimiski Island showed considerable year-to-year variance in nutrient allocations, similar to the Cape Churchill Peninsula colony (Fig. 2).

Sensitivity analysis.-Because we used isotopic discrimination derived from the carnivore model of Hobson (1995) to estimate that associated with the mobilization of endogenous nutrients to egg components (Gauthier et al. 2003), we tested the effect of considering no discrimination (i.e., the complete mobilization of proteins from muscle to egg protein without isotopic change). For the Cape Churchill birds breeding in 2005, this assumption resulted in a change in the Bayesian (SIAR) estimate of endogenous contributions of protein to egg albumen and yolk protein by less than $2.0 \%$. However, a similar analysis of the Bylot Island data for 1999 resulted in an increase in mean endogenous contributions of $18.0 \%$ for albumen and $9.0 \%$ for yolk.

The use of the concentration-dependent Bayesian mixingmodel SIAR allowed a much more useful incorporation of error in our estimates of endogenous contributions to eggs. The use of a two-isotope model also allows for the resolution of three isotopically different inputs and should generally provide finer resolution than a single-isotope model. However, this (SIAR) model will always attempt to fit a solution to the data used, even if some values fall outside of the traditional mixing-model convex polygon

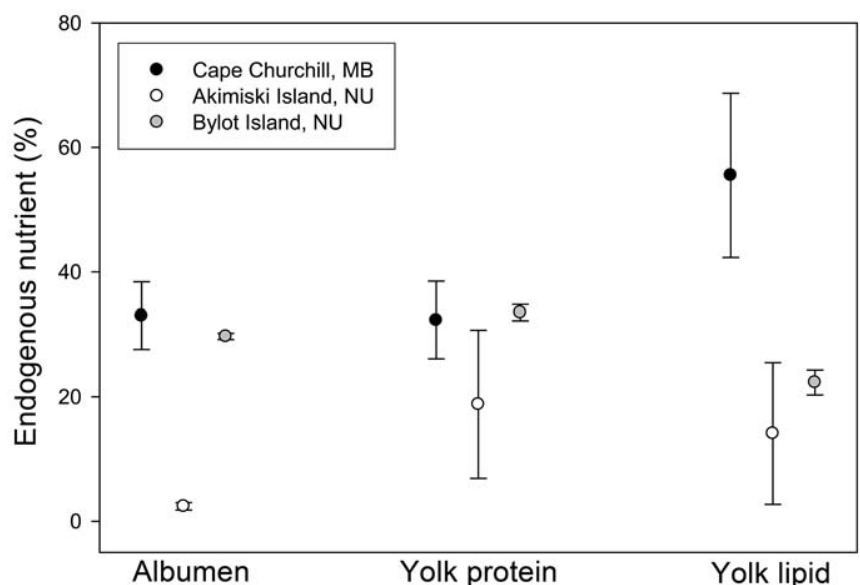

FIG. 2. Comparison of endogenous nutrient allocations to eggs of snow geese from different studies. All data sets were analyzed using the same Bayesian (SIAR) statistical approach. Error bars are SE. (but with consequences for the range of the $95 \%$ confidence interval). Therefore, we also examined the predictions for endogenous versus exogenous inputs to eggs using a two-source, one-isotope $\left(\delta^{13} \mathrm{C}\right)$ model for Cape Churchill birds in all years. After applying isotopic discrimination values described above for $\delta^{13} \mathrm{C}$, all egg isotope values fell between endogenous and exogenous endpoints. The results of this analysis are presented in the Appendix. Mean endogenous contributions to eggs across years were 47.8 $\pm 5.9 \%$ for albumen and $43.6 \pm 6.6 \%$ for yolk protein. These averaged $14.8 \%$ and $11.3 \%$ higher than estimates derived from the twoisotope, three-source SIAR model results for albumen (paired sample $t$-test, $t=9.35, \mathrm{df}=3, P=0.003)$ and yolk protein $(t=12.41$, $\mathrm{df}=3, P=0.001$ ), respectively. Trends based on both analytical approaches were well correlated across years for yolk protein $\left(r^{2}=0.96, P=0.04\right)$, but less so for albumen $\left(r^{2}=0.85, P=0.15\right)$.

Effect of yolk sampling position in eggs collected in 2005.-No effect of yolk sampling position (i.e., inner, middle, outer) was found for lipid-free yolk $\delta^{13} \mathrm{C}$ (inner $=-25.7 \pm 1.0 \%$, middle $=-26.2$ $\pm 0.7 \%$, outer $=-25.7 \pm 0.8 \% ; F=0.40, \mathrm{df}=2$ and $20, P=0.68)$, lipid-free yolk $\delta^{15} \mathrm{~N}$ (inner $=7.0 \pm 1.0 \%$, middle $=6.3 \pm 1.0 \%$, outer $=$ $6.5 \pm 0.9 \% ; F=0.45, \mathrm{df}=2$ and $20, P=0.65$ ) or for yolk lipid $\delta^{13} \mathrm{C}$ (inner $=-27.7 \pm 0.9 \%$, middle $=-27.4 \pm 0.6 \%$, outer $=-27.8 \pm 1.5 \%$; $F=0.26, \mathrm{df}=2$ and $20, P=0.70$ ).

Isotopic relationships among egg components.-We found generally strong linear associations between stable-isotope values of egg components for each year and each isotope (Fig. 3). However, 2007 consistently showed the strongest linear association and 2005 the weakest association, with the other years (not graphed) being intermediate. A striking difference between 2005 and 2007 was for the linear relationship between $\delta^{13} \mathrm{C}$ of egg lipid and albumen (2005: $Y=0.63 X-10.6 \%, R^{2}=0.07 ; 2007: Y=1.8 X+16.0, R^{2}=$ $0.68)$. The strongest linear association was between $\delta^{13} \mathrm{C}$ of egg yolk lipid and lipid-free yolk in $2007\left(Y=1.7 X+16.0, R^{2}=0.92\right)$.

\section{Discussion}

Population differences.-Our comparison of nutrient allocation strategies between Lesser Snow Geese at the sub-Arctic colony on the Cape Churchill Peninsula and the larger-bodied Greater Snow Goose on Bylot Island in the High Arctic (Gauthier et al. 2003) suggested that although endogenous protein allocations were similar (at 30\%), endogenous lipids contributed much more to eggs of the Lesser Snow Goose. Our reanalysis of Gauthier et al.'s (2003) data set using identical analytical methods showed, over the years 

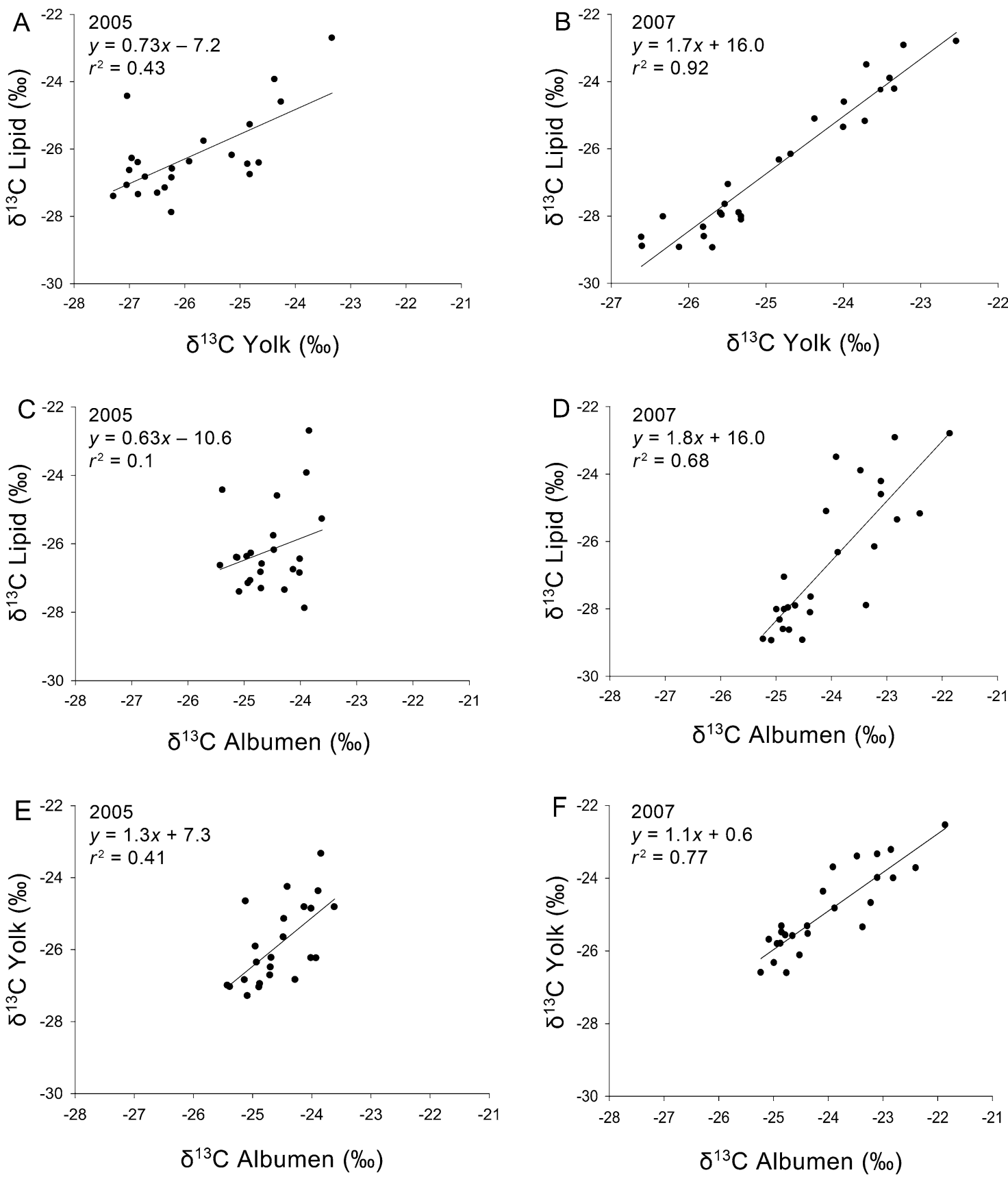

FIG. 3. Linear associations (A-F) between $\delta^{13} \mathrm{C}$ in lipid and protein components of eggs of Lesser Snow Geese collected from nests on the Cape Churchill Peninsula, Manitoba, for individual years (2005 or 2007).

of study, a range of 20.7-24.5\% endogenous lipid contributions for Greater Snow Geese at Bylot compared with 44.2-70.6\% for Lesser Snow Geese. So, despite a smaller body size and a sub-Arctic breeding site, Lesser Snow Geese on the Cape Churchill Peninsula exhibited a much greater tendency for capital breeding. This result does not support the body-size hypothesis, which suggests greater endogenous nutrient contributions to eggs of larger-bodied breeders; or the latitude hypothesis, which suggests that higher-latitude breeders are more inclined to capital breeding because of shorter breeding seasons. Instead, we suggest that our comparative study provides the greatest support for the hypothesis that species with longer migration should invest less of their endogenous reserves in reproduction because their reserves will typically be depleted before arrival and protein reserves may be too costly to transport.

In the case of the Greater Snow Goose on Bylot Island, exogenous contributions to eggs were likely at a peak, especially for protein, given that the birds were known to feed on the island prior to nesting in all 3 years of that study. Gauthier et al. (2003) also 
suggested that the long migration of 3,000 km for the Bylot Island population of Greater Snow Geese from their spring staging areas of southern Quebec precludes the transport of significant amounts of stored fat for reproduction. Migratory fuel stores contain $6-20 \%$ protein (Sotherland and Rahn 1987, Jenni and JenniEiermann 1998, Klaassen 2003), which is much lower than the $60 \%$ protein (on a dry-weight basis) of eggs. Hence, endogenous protein is not as likely as endogenous lipids to be transported via migration for forming eggs.

As suggested by G. Gauthier (pers. comm.), an interesting consequence of our study is that because birds with long and costly migration typically breed at high latitudes, where the breeding season is short, their reliance on an income strategy should force them to use only the most suitable habitats, such as Arctic oases, where the spring season is early and food availability high for the latitude. At our low-latitude site at Cape Churchill, shorter migration distances allowed geese to arrive with endogenous stores, which permitted them to use a site where local conditions often delay the onset of spring.

Our comparison of nutrient allocation data from Lesser Snow Geese on Akimiski Island during the same years as our own study demonstrates that even within a population (i.e., midcontinent) and subspecies, considerable variation in nutrient allocations to eggs occurs between colonies. The more southern colony on Akimiski Island generally showed much lower endogenous nutrient allocations to first eggs than the more northern Cape Churchill Peninsula colony. However, rather than this being a simple latitudinal effect resulting in a longer breeding season at Akimiski Island and, hence, less need to use endogenous nutrients during egg formation, it is clear that local conditions (e.g., snow cover, temperature) at these colonies can influence how nutrients are allocated in any particular year.

Within-population variation.-The results presented here, like those of Gauthier et al. (2003) and the other studies cited above, indicate that different patterns of foraging prior to nesting are to be expected within a species, both at the subpopulation (colony) level and among years. In the case of the Lesser Snow Goose, agricultural lands in the U.S. Midwest, the Canadian Prairies, and the wetlands of the Hudson Bay Lowlands provide a source of high-protein nutrients, whose relative annual contributions to egg production are dependent on seasonal weather conditions and the relatively short migration distance compared with that undertaken by Greater Snow Geese. The net effect is that endogenous nutrients from agricultural sources are likely to be represented, although a substantial intake of nutrients from sub-Arctic sources occurs before the birds initiate egg laying. Other examples of within-species variation include the Brant (Ankney 1984, Spaans et al. 1993, Schmutz et al. 2006).

Overall, the evidence for interannual variation in the relative contribution of protein and lipid in endogenous reserves to egg formation at the Cape Churchill Peninsula colony depended on the particular component under consideration and the year. There was no significant annual variation in albumen protein, but yolk protein and yolk lipid were significantly different depending on the year (Table 3 and Fig. 2). The timing of the late winterearly spring transition was similar in 2007 and 2008. Lesser Snow Geese arrived on the Cape Churchill Peninsula on 20 May 2007 and 22 May 2008, whereas in 2006, when snow melt occurred earlier, the geese arrived earlier. In 2005, there was a late arrival of the geese, coincident with a late snow melt. Hence, the different contributions of endogenous protein and lipid to egg formation do not appear to be directly correlated with local weather events.

Sampling position of yolk in the egg cross sections had little effect on stable isotope values of macronutrients. This suggests that rapid follicular development occurred primarily on the breeding grounds or the coastal wetlands of Ontario and Manitoba. For example, if geese had arrived in the sub-Arctic with centers of the yolk of the first-laid egg already formed and subsequently allocated exogenous nutrients to the remaining portions of the yolk and albumen, we would have expected a strong isotopic effect on sampling position, with the central portion showing generally more enriched $\delta^{13} \mathrm{C}$ values. Instead, it appears that in 2005, birds formed the first laid egg in the Hudson Bay Lowlands and directed both endogenous and exogenous nutrients to its formation.

Proximate factors appear to strongly influence annual nutrient allocation strategies. Ganter and Cooke (1996) reported that Lesser Snow Geese at the traditional breeding area at La Pérouse Bay appeared, on the basis of behavioral observations, to be income breeders in some years. Lesser Snow Geese at that location now have poor foraging opportunities prior to breeding because the site became depleted of food sources (Jefferies et al. 2003, Abraham et al. 2005), limiting access to exogenous nutrients in the immediate vicinity. In the past two decades the colony increased substantially, and geese now feed and nest in coastal wet sedge meadows elsewhere on the Cape Churchill Peninsula where the loss of vegetation is much less. The geese also feed extensively in similar habitats in Ontario and Manitoba en route to the Cape Churchill Peninsula as they track the retreating snowline (Klaassen et al. 2006).

Migration phenology may also be important in explaining why nutrient allocation strategies differ so much between the two sub-Arctic colonies. Lesser Snow Geese at Cape Churchill initiated their nests 2 to 3 weeks later in 2005-2008 than those breeding on Akimiski Island (Sharp 2010) but likely spent much of this time feeding in the James and Hudson Bay lowlands. This staging strategy allows for the replenishment of endogenous stores utilized during the nonstop migration from southern Manitoba to the coasts of Hudson Bay (Abraham and Jefferies 2010: fig 3.1). Values of $\delta^{13} \mathrm{C}$ for abdominal fat from Lesser Snow Geese nesting at La Pérouse Bay were lower than those from birds nesting on Akimiski Island, which suggests that the former acquired considerable nutrients and converted them to endogenous stores while feeding in the Hudson Bay Lowlands (Wypkema and Ankney 1979). The acquisition of nutrient stores close to the breeding grounds (proximate capital; Klaassen et al. 2006) would also help to eliminate much of the cost associated with transport of such stores. These newly acquired nutrient reserves may facilitate the allocation of endogenous nutrients during clutch formation. A lack of exogenous resources and, possibly, a replenishment of endogenous stores following migration may explain the greater reliance on endogenous nutrients for egg formation observed at $\mathrm{La}$ Pérouse Bay. The intraspecific variation in Lesser Snow Geese is an excellent example of how flexibility in nutrient allocation strategy helps members of a species cope with different proximate factors that can influence nutrient availability during reproduction.

Analytical considerations.-The use of isotopic mixing models to estimate endogenous contributions of nutrients to eggs is a relatively new approach to investigations of avian life-history strategies (Hobson 2006) and offers considerable advantages. It 
currently has a major drawback, however, in that we lack a firm understanding of the precise isotopic discrimination factors that link egg macromolecules with their sources. This is especially true of the endogenous-to-egg discrimination factors. We encourage researchers to perform sensitivity analyses to effectively bracket the range of estimates derived. In the present study, we found that using the carnivore model as a proxy for endogenous isotope discrimination from endogenous sources of proteins to eggs, compared with no discrimination, resulted in relatively small changes to estimates of endogenous contributions for the Cape Churchill population. That a larger effect was found in a similar sensitivity analysis for the Bylot Island population suggests that such tests should be applied on a case-by-case basis. Such differences related to isotopic discrimination factors may be due to differing nutritional quality of diets among colonies (e.g., Robbins et al. 2005)

Our comparisons of estimates of the importance of endogenous sources to egg protein using the Bayesian three-source, twoisotope model and the simpler two-endpoint, one-isotope $\left(\delta^{13} \mathrm{C}\right)$ model generally resulted in slightly higher estimates for the oneisotope approach. Again, this will vary from case to case. Nonetheless, because the estimates were within $\sim 15 \%$, our conclusions were not affected greatly by the analytical approach used. Moreover, because we reanalyzed data from other studies that we felt matched our Bayesian approach, inferences based on latitudinal and body-size changes are conservative. We recommend that future studies that investigate differences in use of endogenous reserves among species or populations of migratory birds adopt a consistent analytical tool and investigate the sensitivity of their models to key parameters.

A strong isotopic linear association among egg tissues can be expected for both a capital and an income breeding strategy. This is because in either case, isotopic values of any component are related linearly through the various isotopic discrimination factors operating at each metabolic transition from nutrient source to eggs. Recently, Hobson and Jehl (2010) found strong $\delta^{13} \mathrm{C}$ and $\delta^{15} \mathrm{~N}$ correlations among egg components for a community of shorebirds at Churchill, with data falling along the relationship predicted by the discrimination factors appropriate for a purely income-based strategy as described for eggs by Hobson (1995). Weak isotopic correlation between egg tissues at the community level suggests that the sources of elements to different egg components differed or that individuals differed substantially in their allocation strategies, or both. So, for our Lesser Snow Geese, 2005 was likely a year when lipids and albumen protein were derived from isotopically different sources.

Our study has demonstrated the power of using the stableisotope approach to quantify and monitor sources of nutrients for reproduction in birds that travel to breed. This approach is suited to both population- and individual-level investigations. Future studies that are able to match isotopic signals in laying females and those in their eggs will provide even greater information and allow the investigation of covariates such as body condition, arrival time, and timing of clutch initiation (e.g., Sharp 2010).

\section{ACKNOWLEDGMENTS}

Our research team suffered a great loss with the untimely death of co-author R. L. Jefferies on July 8th, 2009. We dedicate this paper, to which he contributed greatly, to his memory. Agencies that generously supported the project include the Arctic Joint
Goose Venture, the Central and Mississippi Flyway Councils, Natural Sciences and Engineering Research Council of Canada, Department of Indian and Northern Affairs of Canada, Environment Canada, Ontario Ministry of Natural Resources, Churchill Northern Studies Centre, and Hudson Bay Helicopters. We thank C. Balser, C. Paddock, P. Ratson, and D. Webber for providing us with tissue samples of Lesser Snow Geese. B. X. Mora Alvarez assisted with sample preparations for stable-isotope analyses, which were conducted by M. Stocki at the Department of Soil Science, University of Saskatchewan. G. Gauthier and two anonymous reviewers provided valuable comments on an earlier draft of the manuscript.

\section{Literature Cited}

Abraham, K. F., AND R. L. JefFERIES. 2010. White geese and subArctic and Arctic habitats: An updated assessment of processes and impacts. In Second Assessment of Causes, Impacts and Implications of High White Goose Populations in North America (B. D. J. Batt, Ed.). Report of the Arctic Goose Habitat Working Group. Arctic Goose Joint Venture Special Publication. U.S. Fish and Wildlife Service, Washington, D.C., and Canadian Wildlife Service, Ottawa, Ontario. [In press.]

Abraham, K. F., R. L. Jefferies, and R. T. Alisauskas. 2005. The dynamics of landscape change and snow geese in mid-continent North America. Global Change Biology 11:841-855.

ANKNEY, C. D. 1984. Nutrient reserve dynamics of breeding and molting Brant. Auk 101:361-370.

Ankney, C. D., ANd C. D. MacInnes. 1978. Nutrient reserves and reproductive performance of female Lesser Snow Geese. Auk 95:459-471.

Bond, J. C., D. EsLer, AND K. A. Hobson. 2007. Isotopic evidence for sources of nutrients allocated to clutch formation by Harlequin Ducks. Condor 109:698-704.

ChOINIÈRE, L., AND G. GAUTHIER. 1995. Energetics of reproduction in female and male Greater Snow Geese. Oecologia 103:379-389.

Cooke, F., R. F. Rockwell, ANd D. B. LANK. 1995. The Snow Geese of La Pèrouse Bay: Natural Selection in the Wild. Oxford University Press, Oxford, United Kingdom.

DRENT, R. H., AND S. DAAN. 1980. The prudent parent: Energetic adjustments in avian breeding. Ardea 68:225-252.

Ebbinge, B. S., A. St. Joseph, P. Prokosch, and B. SpaAns. 1982. The importance of spring staging areas for Arctic-breeding geese, wintering in western Europe. Aquila 89:249-258.

Ganter, B., And F. Cooke. 1996. Pre-incubation feeding activities and energy budgets of Snow Geese: Can food on the breeding grounds influence fecundity? Oecologia 106:153-165.

Gauthier, G., J. BÊty, And K. A. Hobson. 2003. Are Greater Snow Geese capital breeders? New evidence from a stable-isotope model. Ecology 84:3250-3264.

HoBson, K. A. 1995. Reconstructing avian diets using stable-carbon and nitrogen isotope analysis of egg components: Patterns of isotopic fractionation and turnover. Condor 97:752-762.

Hobson, K. A. 2006. Using stable isotopes to quantitatively track endogenous and exogenous nutrient allocations to eggs of birds that travel to breed. Ardea 94:359-369.

Hobson, K. A., L. Atwell, L. I. Wassenaar, and T. Yerkes. 2004. Estimating endogenous nutrient allocations to reproduction in Redhead Ducks: A dual isotope approach using $\delta \mathrm{D}$ and 
$\delta^{13} \mathrm{C}$ measurements of female and egg tissues. Functional Ecology 18:737-745.

HoBSON, K. A., AND J. R. JEHL, JR. 2010. Arctic waders and the capitalincome continuum: Further tests using isotopic contrasts of egg components. Journal of Avian Biology 41:565-572.

Hobson, K. A., J. Sirois, And M. L. Gloutney. 2000. Tracing nutrient allocation to reproduction using stable-isotopes: A preliminary investigation using the colonial waterbirds of Great Slave Lake. Auk 117:760-774.

Hobson, K. A., J. E. Thompson, M. Evans, And S. Boyd. 2005. Tracing nutrient allocation to reproduction in Barrow's Goldeneye. Journal of Wildlife Management 69:1221-1228.

Jefferies, R. L., R. F. Rockwell, and K. F. Abraham. 2003. The embarrassment of riches: Agricultural food subsidies, high goose numbers, and loss of Arctic wetlands-A continuing saga. Environmental Reviews 11:193-232.

Jenni, L., and S. Jenni-Eiermann. 1998. Fuel supply and metabolic constraints in migrating birds. Journal of Avian Biology 29: 521-528.

KlaAssen, M. 2003. Relationships between migration and breeding strategies in Arctic breeding birds. Pages 237-249 in Avian Migration (P. Berthold, E. Gwinner, and E. Sonnenschein, Eds.) Springer-Verlag, Berlin.

KlaAssen, M., K. F. Abraham, R. L. Jefferies, and M. VRtiska. 2006. Factors affecting the site of investment, and the reliance on savings for Arctic breeders: The capital-income dichotomy revisited. Ardea 94:371-384.

Meijer, T., AND R. H. Drent. 1999. Re-examination of the capital and income dichotomy in breeding birds. Ibis 141:399-414.

Morrison, R. I. G., AND K. A. HobSON. 2004. Use of body stores in shorebirds after arrival on High-Arctic breeding grounds. Auk 121:333-344.

OWEN, R. B., JR., AND K. J. REINECKE. 1979. Bioenergetics in breeding dabbling ducks. In Waterfowl and wetlands-An integrated review. Pages 71-93 in Proceedings of a Symposium. 39th Fish and Wildlife Conference (T. A. Bookhour, Ed.). La Crosse Printing, La Crosse, Wisconsin.

Parnell, A. C., R. Inger, S. Bearhop, and A. L. Jackson. 2010. Source partitioning using stable isotopes: Coping with too much variation. PLoS ONE 5(3):e9672.

Phillips, D. L., AND P. L. KocH. 2002. Incorporating concentration dependence in stable isotope mixing models. Oecologia 130: $114-125$.

PORSILD, A. E., AND W. J. CoDy. 1980. Vascular plants of continental Northwest Territories, Canada. National Museums of Canada, Ottawa.
Raveling, D. G. 1978. The timing of egg laying by northern geese. Auk 95:294-303.

Robbins, C. T., L. A. Felicetti, And M. Sponheimer. 2005. The effect of dietary protein quality on nitrogen isotope discrimination in mammals and birds. Oecologia 144:534-540.

RoCKWELL, R. F., AND L. J. GormeZANO. 2009. The early bear gets the goose: Climate change, polar bears and Lesser Snow Geese in western Hudson Bay. Polar Biology 32:539-547.

Ross, R. K., K. F. Abraham, D. Fillman, B. T. Collins, and R. H. KERBES. 2004. A helicopter-based survey method for monitoring the nesting component of snow goose colonies. Northeast Wildlife 58:9-22.

RouSE, W. R. 1991. Impacts of Hudson Bay on the terrestrial climate of the Hudson Bay lowlands. Arctic and Alpine Research 23:24-30.

RYDER, J. P. 1970. A possible factor in the evolution of clutch size in Ross' Goose. Wilson Bulletin 82:5-13.

Schmutz, J. A., K. A. Hobson, AND J. A. Morse. 2006. An isotopic assessment of protein from diet and endogenous stores: Effects on egg production and incubation behavior of geese. Ardea 94: 385-397.

SHARP, C. M. 2010. Factors influencing nutrient allocation during egg formation in sub-Arctic breeding geese. M.Sc. thesis, Trent University, Peterborough, Ontario.

Sotherland, P. R., AND H. Rahn. 1987. On the composition of bird eggs. Condor 89:48-65.

SpaAns, B., M. Stock, A. St. Joseph, H. H. Bergmann, and B. S. EBBINGE. 1993. Breeding biology of dark-bellied Brent Geese, Branta b. bernicla, in Taimyr in 1990 in the absence of Arctic foxes and under favorable weather conditions. Polar Research 12:117-130.

Thomas, V. G. 1988. Body condition, ovarian hierarchies and their relation to egg formation in Anseriform and Galliform species. Pages 353-363 in Acta XIX Congressus Internationalis Ornithologici (H. Ouellet, Ed.). National Museum of Natural Sciences, University of Ottawa Press, Ottawa.

WypKema, R. C. P., AND C. D. ANKNEy. 1979. Nutrient reserve dynamics of Lesser Snow Geese staging at James Bay, Ontario. Canadian Journal of Zoology 57:213-219.

Yerkes, T., K. A. Hobson, L. I. WassenaAR, R. Macleod, and J. M. Coluccy. 2008. Stable isotopes $\left(\delta D, \delta^{13} \mathrm{C}, \delta^{15} \mathrm{~N}\right)$ reveal associations among geographic location and condition of Alaskan Northern Pintails. Journal of Wildlife Management 72:715-725.

Associate Editor: T. Hahn

APPENDIX. Estimates of endogenous contributions (means \pm SE) of protein and lipid to egg formation in Lesser Snow Geese at Cape Churchill Peninsula, Manitoba, across years, using a two-endpoint (endogenous vs. exogenous), one-isotope $\left(\delta^{13} \mathrm{C}\right)$ IsoConc model.

\begin{tabular}{|c|c|c|c|c|c|c|c|c|}
\hline \multirow[b]{2}{*}{ Egg tissue } & \multicolumn{8}{|c|}{ Percent endogenous contribution } \\
\hline & 2005 & Range & 2006 & Range & 2007 & Range & 2008 & Range \\
\hline Albumen & $39.18 \pm 3.83$ & $16.0-78.7$ & $51.27 \pm 4.01$ & $23-54.2$ & $52.14 \pm 3.67$ & $26.6-90$ & $48.67 \pm 3.30$ & $23-94$ \\
\hline Yolk & $38.44 \pm 3.53$ & $24.2-51.8$ & $39.42 \pm 3.74$ & $39.2-85.6$ & $52.86 \pm 3.43$ & $27.1-100$ & $43.55 \pm 3.08$ & $23.5-100$ \\
\hline Yolk lipid & $71.31 \pm 4.27$ & $46.8-100$ & $45.74 \pm 4.69$ & $24.9-90$ & $60.61 \pm 4.10$ & $28.4-100$ & $43.64 \pm 3.68$ & $8.6-100$ \\
\hline
\end{tabular}

